\title{
Synovial sarcoma of the tongue: report of a case and review of the literature
}

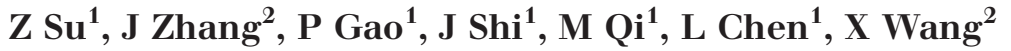 \\ ${ }^{1}$ School of Stomatology, Shandong University, Jinan City, Shandong Province, China \\ ${ }^{2}$ Stomatological Hospital of Shandong University, Jinan City, Shandong Province, China \\ ABSTRACT \\ This report outlines the work-up and management of a 35-year-old man with a synovial sarcoma of the lateral border of the \\ tongue. Synovial sarcoma of the tongue is an extremely rare tumour with variable morphological microscopic types and charac- \\ ters of immunohistochemical profile. There have only been 15 cases previously reported. This report aims to update the litera- \\ ture on this subject and explore the best treatment options.
}

KEYWORDS

Synovial sarcoma - Immunohistochemistry

Accepted 14 January 2018

CORRESPONDENCE TO

Xuxia Wang, E: wxx@sdu.edu.cn

\section{Introduction}

Synovial sarcoma is a soft tissue sarcoma with variable morphological and genetic characteristics. Synovial sarcoma often occurs in the head and neck, including the parapharyngeal space and parotid gland. Synovial sarcomas of the tongue are extremely rare and diagnosis of these tumours is complicated. We describe the diagnosis and management of a 35-year-old man with a synovial sarcoma of the lateral left side of the tongue, which was initially diagnosed as a haemangioma. Given its rarity, we believe that this case is worthy of reporting and comparison with previously reported cases located in the same anatomical site to explore the best treatment options.

\section{Case history}

A 35-year-old man noticed a mildly painful, non-mobile lump on the left side of his tongue one year before presentation. The patient described the initial tumour as being the size of a quail's egg. The tumour produced a progressive speech impairment and led to difficulty in food intake. One month after first noticing the lump, the patient underwent a magnetic resonance imaging (MRI) examination at the local hospital. Haemangioma was diagnosed. Subsequently, he underwent further evaluation and management at the Stomatological Hospital of Shandong University. Blood analysis indicated that he had hepatitis b. The patient denied smoking and drinking.

Intraoral examination revealed a $4 \times 4 \times 3 \mathrm{~cm}$ mass located on the posterior third of the left side of the tongue. The mass was solid and painless on palpation. The colour of the mucosa of lingual dorsum was normal. Tongue movements were partially restricted (Fig 1). No enlarged lymph nodes were noted on either side of the neck. MRI of the head and neck revealed the presence of a large tumour occupying the left side of the tongue (Figs 2 and 3). The panel of oral and maxillofacial surgery experts assessed the patient and recommended surgical excision of the tumour. The malignant nature and vasculature of the tumour was not clear, as assessed by clinical manifestation and MRI. Given that a preoperative biopsy may have led to excessive bleeding, we prepared an intraoperative frozen biopsy.

No capsule was present around the tumour and it infiltrated peripheral tissue (Fig 4). The pathology result did not exclude a low degree of malignancy, but a clear diagnosis was not obtained. We decided to remove the tumour completely. Given the defective tissue, we used local flap repair to remodel the tongue (Fig 5).

The histopathological report of the surgical specimen revealed a synovial sarcoma of the tongue. Immunohistochemical analysis was positive for epithelial membrane antigen (EMA) and CD99. The pathology report confirmed wide tumour-free surgical margins.

According to the 2017 National Comprehensive Cancer Network (NCCN) Clinical Practice Guidelines in Oncology of soft tissue sarcoma, this patient had a T2N0M0 tumour. The tumour was classified as stage IIB based on NCCN guidelines. Tumours of this stage should primarily be managed by en-bloc resection to obtain oncologically appropriate margins, followed by radiation therapy and adjuvant chemotherapy. However, there are limited and conflicting data regarding the potential benefits of adjuvant 


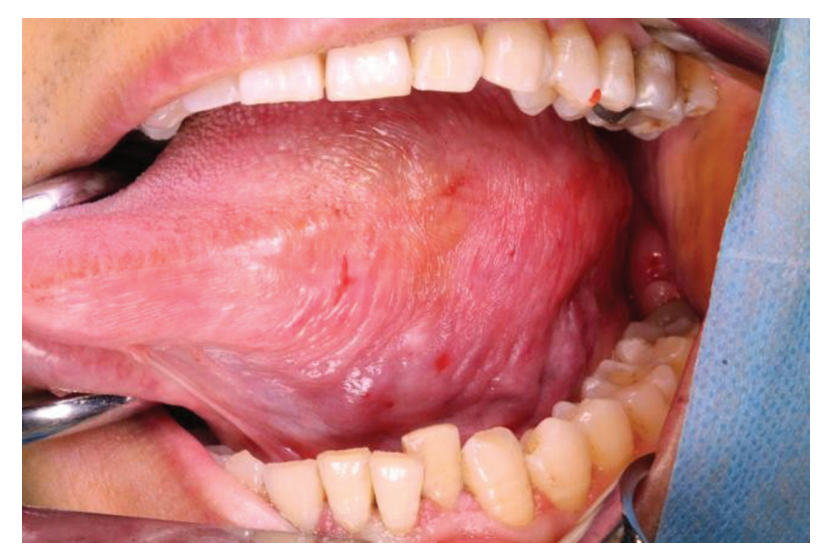

Figure 1 Initial presentation showing a mass in the left side of the tongue

chemotherapy at stage II. $^{1}$ The patient ultimately chose adjuvant radiotherapy alone. After receiving a course of radiation therapy, the patient was reviewed at our hospital. The incision healed well and his tongue movement improved. MRI revealed no enlarged lymph nodes in the neck. The patient received regular follow-up with routine blood examination and interval imaging of his head and chest to assess for relapse or pulmonary metastasis. He

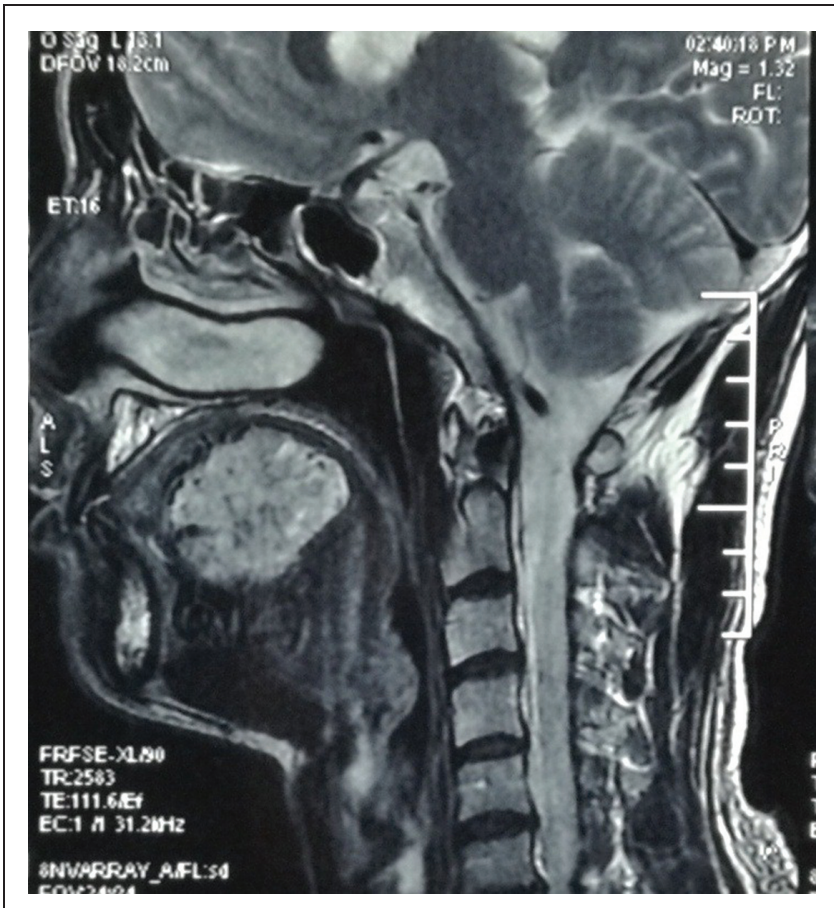

Figure 2 Preoperative T2-weighted magnetic resonance image showing a well-defined, ovoid, circumscribed mass can be depicted

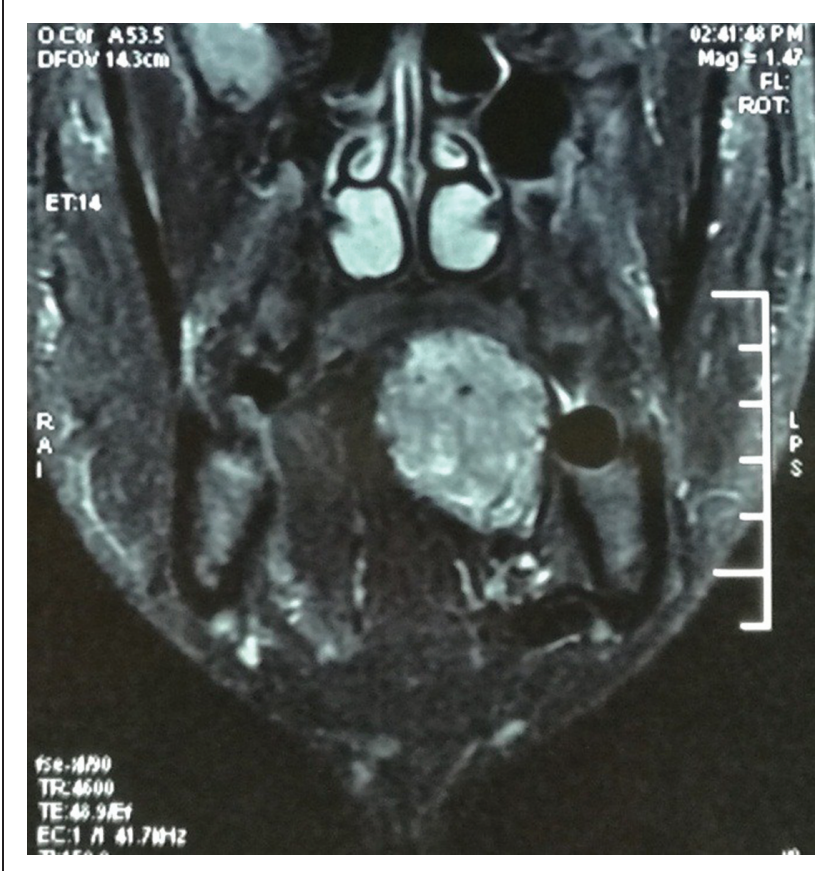

Figure 3 Preoperative T2-weighted magnetic resonance image; the mass can be seen occupying the middle and posterior third but not extending to the base of the tongue

continues with a follow-up regimen: every two months for two years, then every six months for the following two years, and then annually. He is currently one-year diseasefree with no evidence of metastasis.

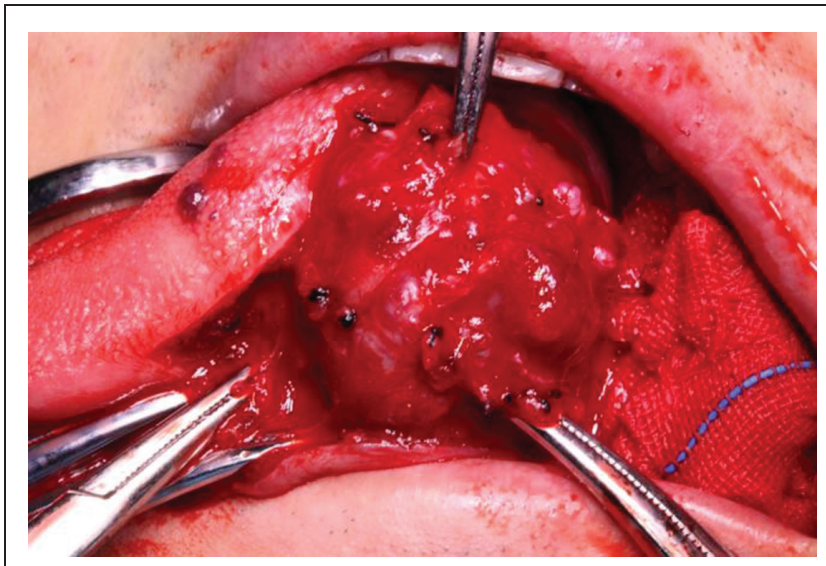

Figure 4 Intraoperative image of resected tongue specimen; there was no capsule around the tumour 


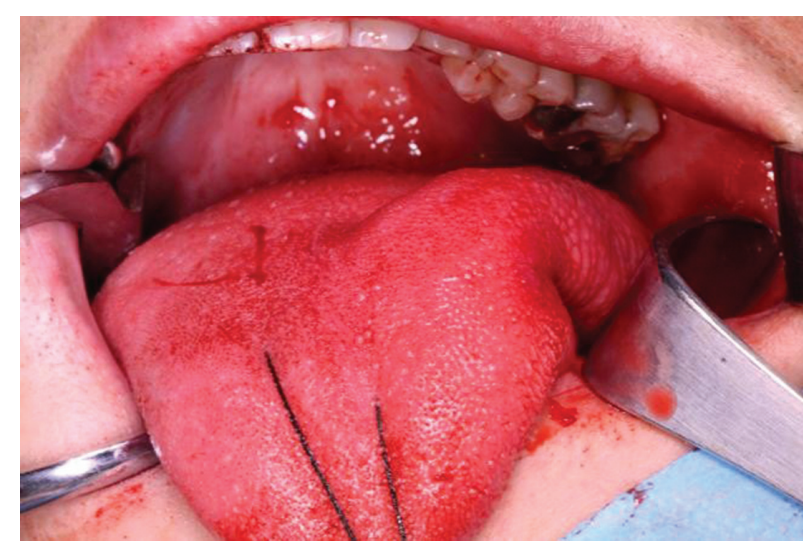

Figure 5 Final closure

\section{Discussion}

Synovial sarcoma is a soft tissue sarcoma with characteristic morphological and genetic features. Synovial sarcoma often occurs in the limbs near the joints, head and neck, parapharyngeal space and parotid gland. In the oral cavity, synovial sarcomas can occur in the buccal mucosa, gingivobuccal sulcus, soft and hard palates, floor of the mouth, retromolar region, submental region and tongue. ${ }^{2}$ However, less than 100 cases have been reported in the literature. Involvement of the tongue by synovial sarcoma is a rare event. Only 15 cases of synovial sarcoma originating in the tongue have been reported (Table 1). ${ }^{3-12}$ An analysis of these cases reveals a striking male predilection. Approximately $81.25 \%$ patients are male and the average age of morbidity is 27 years. The base of the tongue appears to be the most frequent site for synovial sarcoma $(62.5 \%)$. The most common treatment is surgical excision with adjuvant radiotherapy and three of these patients with metastases received follow-up by survey.

Early tumour growth is slow and the location is deep. A sudden increase in symptoms is often noted many years

\begin{tabular}{|c|c|c|c|c|c|c|c|c|}
\hline Case & Reference & Year & $\begin{array}{l}\text { Age } \\
\text { (years) }\end{array}$ & Gender & Site & Size $(\mathrm{cm})$ & Management & Follow-Up \\
\hline 1 & Mir-Abedy & 1962 & 23 & $\mathrm{~F}$ & Base of tongue & 5 & Surgery & Alive and well, 3 years \\
\hline 2 & Novotny and Fort & 1971 & 20 & M & Base of tongue & $3.5 \times 2$ & Radiotherapy & Alive and well, 2 years \\
\hline 3 & $\begin{array}{l}\text { Moussavi and } \\
\text { Ghodsi }\end{array}$ & 1974 & 21 & M & Base of tongue & $6 \times 5 \times 5$ & $\begin{array}{l}\text { Surgery, } \\
\text { radiotherapy }\end{array}$ & Alive and well, 1.3 years \\
\hline 4 & $\begin{array}{l}\text { Guzman Patraca } \\
\text { et al. }\end{array}$ & 1975 & 21 & M & Base of tongue & 7 & Surgery & A with metastases, 1 year \\
\hline 5 & Shmookler et al. & 1982 & 16 & M & Dorsal tongue & 1.2 & Surgery & Alive and well, 8 years \\
\hline 6 & $\begin{array}{l}\text { Engelhardt and } \\
\text { Leafstedt }\end{array}$ & 1983 & 25 & M & Base of tongue & NR & Surgery & Not recorded \\
\hline 7 & $\begin{array}{l}\text { Holtz and } \\
\text { Magielski }\end{array}$ & 1985 & 16 & M & Base of tongue & $6 \times 5 \times 4$ & $\begin{array}{l}\text { Surgery, } \\
\text { radiotherapy, } \\
\text { chemotherapy }\end{array}$ & $\begin{array}{l}\text { Dead of disease, } 37 \text { months } \\
\text { after surgery with metatases }\end{array}$ \\
\hline 8 & Bridge et al. & 1988 & 31 & M & Base of tongue & $3 \times 3$ & Surgery & Not recorded \\
\hline 9 & Carrillo et al. & 1993 & 13 & M & Lateral tongue & $1.1 \times 5 \times 5$ & Surgery & Alive and well, 1 year \\
\hline 10 & $\begin{array}{l}\text { Fortuño-Mar } \\
\text { et al. }\end{array}$ & 2000 & 26 & M & Base of tongue & 5 & $\begin{array}{l}\text { Surgery, } \\
\text { radiotherapy }\end{array}$ & Alive and well, 18 months \\
\hline 11 & Komis et al. & 2008 & 49 & M & Lateral tongue & $3 \times 4.5 \times 4$ & Surgery & $\begin{array}{l}\text { Alive with metastases to lung } 2 \\
\text { years }\end{array}$ \\
\hline 12 & $\begin{array}{l}\text { de Almeida- } \\
\text { Lawall et al. }\end{array}$ & 2009 & 26 & M & Lateral tongue & $1 \times 1$ & Surgery & Alive and well, 18 months \\
\hline 13 & Agarwal et al. & 2009 & 22 & M & Base of tongue & $5 \times 3 \times 2$ & $\begin{array}{l}\text { Surgery, } \\
\text { radiotherapy }\end{array}$ & Not recorded \\
\hline 14 & $\begin{array}{l}\text { Villaroel- } \\
\text { Salinas et al. }\end{array}$ & 2012 & 32 & $\mathrm{~F}$ & Base of tongue & $3.5 \times 2 \times 2$ & Surgery & Not recorded \\
\hline 15 & Basile et al. & 2016 & 55 & $\mathrm{~F}$ & Lateral tongue & $2 \times 2$ & $\begin{array}{l}\text { Surgery, } \\
\text { radiotherapy }\end{array}$ & Alive and well, 2 years \\
\hline 16 & Present case & 2017 & 35 & M & Lateral tongue & $4 \times 3.5 \times 2$ & $\begin{array}{l}\text { Surgery, } \\
\text { radiotherapy }\end{array}$ & Alive and well, 1 year \\
\hline
\end{tabular}



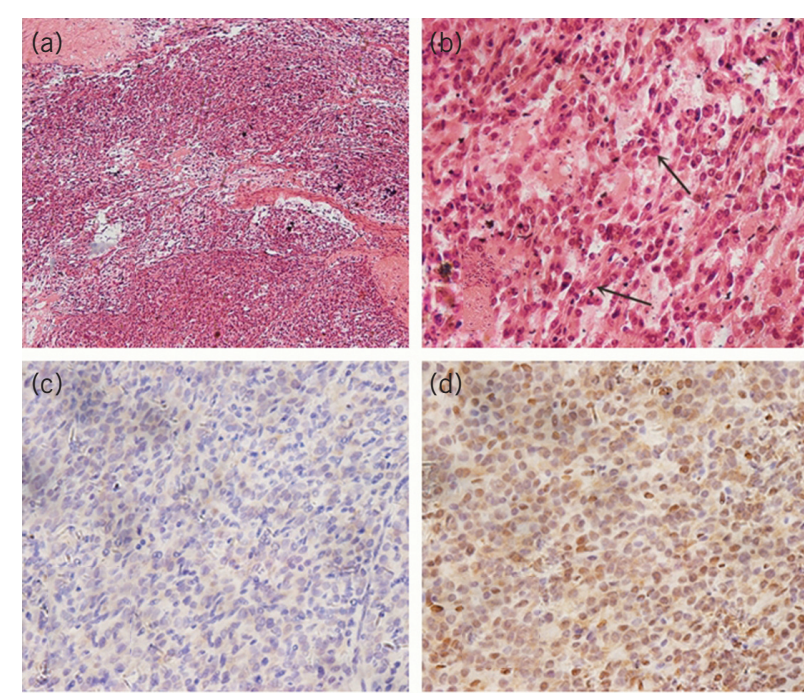

Figure 6 A) Low-power microphotograph of the histological specimen (hematoxylin and eosin stain; $\times 200$ ). B) Higher magnification of the same lesion. Biphasic pattern of synovial sarcoma with a mixture of epithelial cells and spindle-shaped cells (narrow) (hematoxylin and eosin stain; $\times 400$ ). C) Positivity of epithelial component for epithelial membrane antigen (EMA stain; $\times 400$ ). D) The immunohistochemical stain with the nuclear antigen shows strong positivity (CD99 stain; $\times 400)$

after tumour initiation and this early growth process can occur for one to four years. Its clinical manifestations are related to the tumour growth site and include a tumour mass, dysphagia, pain, hoarseness, headache and hearing loss. Surgical resection is recommended, followed by consideration of adjuvant radiotherapy with or without chemotherapy. ${ }^{13}$

Synovial sarcoma imaging is not specific, but MRI is significant for determining the primary site and presence of adjacent tissue infiltration and lymph node metastasis. MRI is the most commonly used imaging method for the diagnosis of soft tissue tumours and the boundaries of soft tissue tumours are depicted. ${ }^{14.15}$ Synovial sarcoma has no characteristic diagnostic markers. Thus, several antibody markers are often used to exclude many morphologically similar sarcomas or carcinomas. Histologically, synovial sarcoma is mainly described as biphasic (25\%), monophasic fibrous or monophasic epithelial $(70 \%)$, poorly differentiated (less than $5 \%$ ) or myxoid variant. ${ }^{16,17}$ These tumours present microscopically with two distinct cell populations, contain epithelial-like cells in glandular structures and spindle cells, and exhibit biphasic differentiation. Migration is noted between spindle cells and epithelial-like cells (Fig 6a,b). Immunohistochemical staining is necessary for the accurate diagnosis of synovial sarcoma. According to available reports, $90 \%$ of synovial sarcomas stain positive for focal cytokeratins and EMA. EMA is the most sensitive indicator of synovial sarcoma expression markers with a sensitivity of
$91 \%$ ( $74 \%$ of which is clearly stained) and specificity of $82 \%$. The overall sensitivity of cytokeratins was $70 \%$ and specificity was $68 \%{ }^{18}$ In this case, immunochemistry revealed that the tumour was positive for EMA and CD99 (Fig 6c,d). Negative immunohistochemical staining also has a diagnostic value in excluding morphological similar tumours. Immunoreactivity for cytokeratins, smooth muscle actin, desmin and myogenin has not been described. After consultation with pathologists, the disease was diagnosed as synovial sarcoma.

Synovial sarcomas yield variable results in immunohistochemical staining, but chromosomal studies revealed that the balanced reciprocal translocation $\mathrm{t}(\mathrm{X} ; 18)$ ( $\mathrm{p} 11.2 \mathrm{q}$; $\mathrm{q} 11.2$ ) is found in more than $90 \%$ of all synovial sarcoma subtypes. ${ }^{19}$ This translocation results in a fusion of the $S Y T$ or $S S X T$ gene from chromosome 18 to the $S S X 1, S S X 2$ or $S S X 4$ genes from the X-chromosome. The SYT-SSX fusion transcript has high diagnostic value in synovial sarcoma. Molecular testing is not required, however, if the diagnosis of synovial sarcoma is certain and based on clinical and histological evaluation. Thus, this testing was not performed for this case.

Surgery is an important means of treating head and neck synovial sarcoma, which is key to reducing recurrence and metastasis, but the recurrence rate is very high (greater than $70 \%) .^{20}$ The reasons for this finding include the following points. The lack of capsule formation leads to incomplete surgical removal, especially at the base of the skull and infratemporal fossa. The head is rich in blood vessels and nerves, and widespread removal of the tumour may result in dysfunction or even death. The tumour is easily misdiagnosed, which causes repeated recurrence after surgery, thereby increasing the risk of distant metastasis and lymph node metastasis, eventually leading to treatment failure. Most scholars believe that the surgical margin and tumour size are key factors that affect disease prognosis. ${ }^{16,21}$ Reduced lymph node metastases are noted in synovial sarcoma of the head and neck. Unless distinct enlarged lymph nodes are present, preventive cervical lymph node dissection is not recommended. ${ }^{21}$ Fayda $e t a l$. believe that chemoradiotherapy is a better option for treating head and neck synovial sarcoma. The recommended total dose is $65 \mathrm{~Gy}$ and ifosfamide is the main chemotherapy. ${ }^{23,24}$

Radiotherapy improves disease-free survival in the majority of patients. ${ }^{25}$ According to the 2017 NCCN Clinical Practice Guidelines in Oncology of soft tissue sarcoma (version 2), ${ }^{1}$ postoperative radiotherapy in the range of 45 Gy for a low-dose rate or a high-dose equivalent is recommended. If the dose is too high, it will lead to adverse effects, such as radiation mucositis, ulceration and osteoradionecrosis. ${ }^{26}$ The clinical and radiological manifestations of synovial sarcoma are not easily distinguished from those of other soft tissue sarcomas and its pathophysiology is diverse. Doctors are less aware of this condition, which is highly misdiagnosed. The clinical and radiological manifestations are determined by fluorescence in situ hybridisation when necessary and this test should be used to reduce the risk of misdiagnosis. Given its rarity, the treatment plan efficacy should be verified in 
more cases. Further studies are needed to determine the long-term outcome.

\section{References}

1. National Comprehensive Cancer Network. Soft Tissue Sarcoma, version 2.2017 Fort Washington, PA: NCCN; 2017

2. Al-Daraji W, Lasota J, Foss R, Miettinen M. Synovial sarcoma involving the head: analysis of 36 cases with predilection to the parotid and temporal regions. Am J Surg Pathol 2009; 33: 1,494-1,503.

3. Engelhardt J, Leafstedt SW. Synovial sarcoma of tonsil and tongue base. South Med J 1983; 76: 243-244.

4. Fortuño-Mar A, Mayayo $\mathrm{E}$, Guiral $\mathrm{H}$ et al. [Synovial sarcoma of the tongue: case report and review of the literature.] An Otorrinolaringol Ibero Am 2000; 27 323-331.

5. Carrillo R, el-Naggar AK, Rodriguez-Peralto JL, Batsakis JG. Synovial sarcoma of the tongue: case report and review of the literature. J Oral Maxillofac Surg 1992; 50: 904-906.

6. Ghodsi S, Sadr AM, Moussavi A. Synovial sarcoma of the tongue: report of a case. Acta Med Iran 1974; 88: 155-160.

7. Guzman PC, Ortiz TH, Garza GR. Synovial sarcoma of the oral cavity (foramen caecum): report of a case and review of the literature. Prensa Med Mex 1975; 40: 215-220.

8. Holtz F, Magielski JE. Synovial sarcomas of the tongue base: the seventh reported case. Arch Otolaryngol 1985; 111: 271-272.

9. Bridge J A, Bridge R S, Borek D A et al. Translocation $t(X ; 18)$ in orofacial synovial sarcoma. Cancer 2015; 62: 935-937.

10. Komis C, Lagogiannis GA, Faratzis G, Rapidis AD. Synovial sarcoma of the tongue: report of a case and review of the literature. J Oral Maxillofac Surg 2008; 66: 154-160.

11. Novotny GM, Fort TC. Synovial sarcoma of the tongue. Arch Otolaryngol Head Neck Surg 1971; 94: 77-79.

12. Shmookler BM, Enzinger FM, Brannon RB. Orofacial synovial sarcoma: a clinicopathologic study of 11 new cases and review of the literature. Cancer 1982; 50: 269-276.
13. Basile LE, Hoch B, Dillon JK. Synovial sarcoma of the tongue: report of a case. J Oral Maxillofac Surg 2016; 74: 95-103.

14. Murphey MD, Smith WS, Smith SE et al. From the archives of the AFIP. Imaging of musculoskeletal neurogenic tumors: radiologic-pathologic correlation. Radiographics 2006; 26: 1,543-1,565.

15. Hirsch RJ, Yousem DM, Loevner LA et al. Synovial sarcomas of the head and neck: MR findings. AJR Am J Roentgenol 1997; 169: 1,185-1,188.

16. Komis C, Lagogiannis GG, Rapidis A. Synovial sarcoma of the tongue: report of a case and review of the literature. J Oral Maxillofac Surg 2008; 66: 154-160.

17. Villaroel-Salinas J, Campos-Martinez J, Ortiz-Hidalgo C. Synovial sarcoma of the tongue confirmed by molecular detection of the SYT-SSX2 fusion gene transcript. Int J Surg Pathol 2012; 20: 386-389.

18. Olsen SH, Thomas DG, Lucas DR. Cluster analysis of immunohistochemical profiles in synovial sarcoma, malignant peripheral nerve sheath tumor, and Ewing sarcoma. Mod Pathol 2006; 19: 659-668.

19. Naka N, Takenaka S, Araki $\mathrm{N}$ et al. Synovial sarcoma is a stem cell malignancy. Stem Cells 2010; 28: 1,119-1,131.

20. Lagrange JL, Ramaioli A, Chateau MC et al. Sarcoma after radiation therapy: retrospective multiinstitutional study of 80 histologically confirmed cases. Radiation Therapist and Pathologist Groups of the Federation Nationale des Centres de Lutte Contre le Cancer. Radiology 2000; 216: 197-205.

21. Agarwal AP, Shet TM, Joshi R et al. Monophasic synovial sarcoma of tongue. Indian J Pathol Microbiol 2009; 52: 568-570.

22. Kartha SS, Bumpous JM. Synovial cell sarcoma: diagnosis, treatment, and outcomes. Laryngoscope 2002; 112: 1,979-1,982.

23. Bilgic B, Mete Ö, Öztürk AS et al. Synovial sarcoma: a rare tumor of larynx. Pathol Oncol Res 2003; 9: 242-245.

24. Fayda M, Aksu G, Agaoglu FY et al. The role of surgery and radiotherapy in treatment of soft tissue sarcomas of the head and neck region: review of 30 cases. J Craniomaxillofac Surg 2009; 37: 42-48.

25. Yang JC, Chang AE, Baker AR et al. Randomized prospective study of the benefit of adjuvant radiation therapy in the treatment of soft tissue sarcomas of the extremity. J Clin Oncol 1998; 16: 197-203.

26. Meer S, Coleman H, Altini M. Oral synovial sarcoma: a report of 2 cases and a review of the literature. Oral Surg Oral Med Oral Pathol Oral Radiol Endod 2003; 96: 306-315. 